\title{
EDUARD SIEVERS
}

November 25, 1850-March 30, 1932

Sievers was born at Lippoldsberg near Kassel, Germany. He attended the universities of Berlin and Leipzig, and at the latter institution profited especially by the instruction of Zarncke. In his twenty-first year he received a call to Jena as extraordinary professor of Germanic and Romance philology. He responded to calls to Tübingen, Halle, and Leipzig (1892), where he succeeded his old teacher, Zarncke. He remained in Leipzig till the end of his life and died there as professor emeritus on March 30, 1932.

His dissertation on The Old High German Tatian (1870) led to an edition of this text (1872), which in its second edition (1892) presents a model performance as to text and treatment of phonology, and a complete glossary. In 1875 appeared his monograph "Der Heliand und die angelsächsische Genesis, in which he proved that part of the AngloSaxon work, the so-called Genesis B, is a translation from Old Saxon. The correctness of this assertion was proved beyond controversy when Zangemeister in 1894 discovered in the Vatican Library a fragment of the original Old Saxon version. His excellent edition the two texts of the Old Saxon Heliand appeared in 1878. In 1882 was published his Angelsächsische Grammatik, which, with due credit to Sweet's fundamental work on the true dialect distinctions of Old English, marked a vast progress over all previous efforts. Improved editions $(1886,1898)$ further confirmed the standard character of the work. As early as 1876 Sievers published his Grundziuge der Lautphysiologie. It was the first phonetic work of real service to the linguist and introduced to German scholarship the phonetic principles of Bell and Sweet. A fifth edition of this valuable work appeared in 1901. Phonetic and linguistic studies led Sievers to the study of alliterative verse. Basing his investigation to a large extent on the earlier work of Rieger, he established by statistical methods the five "types" of alliterative verse (1884). The results became conveniently available in his Altgermanische Metrik (1893), which also contained a discussion of the probable development of alliterative verse from older types of versification. In the present account, necessarily of a summary nature, many articles, published in the main in Paul und Braune's Beiträge, have not found mention.

Toward middle life Sievers' interest concentrated more and more on the nature of rhythm and melody in speech. He became acquainted with 
the theories of Ohmar Rutz in reference to the various methods of voice production. He discovered that these types of voice production could be induced by the mere sight and movement of wires of various shapes ("optic signals" of Sievers), especially in persons of the motor type. He discovered, furthermore, modifying observations made by Dr. Gustav Becking, that each individual has a "personal curve," a movement of the arms applicable, while producing voice, in only one form specific to the individual and retained by him through life. A false curve would disturb the voice. Sievers felt himself capable of drawing from texts th exact qualities of the voice occurring in each passage and boldly stated his results, in numerous publications which if accepted would frequently lead to radical textual criticism. While his theories found approval with many of the most competent authorities of the day, many considered themselves incompetent to venture a judgment, while still others dissented strongly. This is not the place for comment on these controversial questions. In any case Sievers' command of the older Indo-European, the Semitic, and the modern languages - he spoke English almost as well as his native German-made it possible for him to extend the application of his latest theories to a wide field. (A convenient bibliography for works of this period will be found in Ipsen-Karg, Schallanalytische Versuche, 1928.)

Sievers was singularly unaffected in his manner. Nevertheless, in all his association with him, the writer had the feeling of never before having come into close contact with a man of like mental calibre. He retained his faculties to a remarkable degree till the end of his life. The very simplicity of his manner was felt to be a manifestation of that same faculty that made him the great empiricist of unerring judgment among the linguists of his country. Where his earlier opinions needed correction the correction often was made by himself as his progress continued up to his last days. His voice was well tempered so that it responded easily to the requirements of his "Schallanalyse." Only when he felt that no notice was taken of some of the simpler of his discoveries, the comprehension of which lay within the range of the ordinary philologist, could he be aroused. About a competent successor he seemed to be extremely sceptical. The enthusiasm which distinguished him as a teacher never left him. Not a few of the older generation in Germany, and I may add in America, will remember gratefully the influence of the great master.

FREDERICK H. WILKENS

New York University 